\title{
HVAD ER DET I GRUNDEN, VI REKONSTRUERER?
}

\author{
Diversitet og rekonstruktion af fortidige religioner
}

\author{
Jens Peter Schjødt
}

\begin{abstract}
ENGLISH ABSTRACT: During scholarship within the history of religions there has been a tendency to view religions as coherent systems of thought. They may have changed over time, so that the religious world view of one period would be different from previous and later periods. However, the idea that even within a limited period the religion of different geographical areas, the religion of different individuals and even the religion of one individual ever was coherent does not seem to be realistic compared to what we know of contemporary religion. This article thus aims at discussing some of the problems concerning different kinds of diversity and the consequences these problems have for our reconstructions of past religions. It is concluded that, although there are many more problems than have earlier been realised, we actually can deal with past religions as long as we are aware of the different levels in our sources, distinguishing among other things between the level of local and individual beliefs and habits on the one hand and that of structural features on the other.
\end{abstract}

DANSK RESUMÉ: I religionshistoriens forskningshistorie har der varet en tendens til at se religioner som sammenhongende tankesystemer. Man har nok voret opmcerksom på, at de kunne cendre sig over tid; men man har sjceldent overvejet, om kohcerensen i den religiøse opfattelse i forskellige geografiske områder, hos forskellige individer og selv hos ét og samme individ stemmer overens med det, vi ved om nutidige religioner. Denne artikel søger derfor at diskutere problemer vedrørende forskellige former for diversitet samt de konsekvenser, disse problemer har for vore rekonstruktioner affortidige religioner. Det konkluderes, at skønt der er flere problemer, end man tidligere har erkendt, så er det faktisk muligt at arbejde med fortidige religioner, så lange vi er bevidste om de forskellige niveauer $i$ vore kilder, idet vi skelner mellem lokale og individuelle forestillinger på den ene side og strukturelle karakteristika på den anden.

KEY WORDS: Norse religion, Diversity, Past religions, Reconstruction.

\section{Indledning}

Når man diskuterer nutidige religioner med mennesker, der ikke har nogen religionsfaglig baggrund, bliver det ofte fremhævet, at man skal passe på ikke at generalisere: Ikke 
alle kristne tager Bibelens skabelsesberetning for pålydende, ikke alle muslimer går ind for jihad, ikke alle jøder opfatter Israel som givet af Gud osv. Og det er jo så sandt, som det er sagt: Der er betydelige forskelle i den måde, man forstår og forvalter ens religion på, selv om der i mange tilfælde er skrifter, som principielt skulle være bestemmende for, hvordan man, hvis man anser sig selv for tilhørende en bestemt religion, skal leve, tro og tænke. At man alligevel er nødt til at generalisere for at kunne få sin omverden til at hænge sammen, er en anden sag, der har at gøre med nogle psykologiske og kognitive mekanismer, hvilket jeg kort skal vende tilbage til nedenfor. Men grundlæggende er det en banal erkendelse, at fx kristendom ikke er det samme alle steder og til alle tider, og at det måske eneste, der binder alle kristne sammen, er, at de opfatter sig som kristne.

Interessant er det derfor, at mange religionsforskere i deres daglige virke fremstiller religionerne, som om de var mere eller mindre monolitiske størrelser. Det hænger selvfølgelig sammen med diverse lærebøger, der ganske vist som regel sætter nogle historiske snit: Vedareligionen var både rituelt og forestillingsmæssigt forskellig fra hinduismen, hvilket givetvis er rigtigt. Eller man ved, at forskellige opfattelser kunne medføre nye sekter, der distancerede sig fra 'den oprindelige' religion: Sunni-islam er noget andet end shia-islam. I begge disse tilfælde og i mange andre er man også parat til at medgive eksistensen af skoledannelser og religiøse undergrupperinger. På trods af en sådan erkendelse af diversitet er det imidlertid som regel stadig ganske store blokke, vi står over for; og det er karakteristisk, at man i de fleste tilfælde skelner mellem de forskellige retninger ud fra nogle autoritative skrifter, som i sig selv giver vide rammer for diversitet inden for den enkelte religiøse undergruppering i fortolkningen af disse skrifter. Det betyder ikke, at det ikke er hensigtsmæssigt at skelne mellem fx katolikker og protestanter som grupper med hver sin identitet. Det kan det i høj grad være; men det kommer an på, hvad der lægges i denne skelnen, og om man er bevidst om, at en lang række parametre af primært kulturhistorisk art må tages i betragtning, som, populært sagt, vil forplumre billedet af to distinkte kristne retninger. Afkrævet de teoretiske præmisser vil de fleste forskere være parate til at erkende, at de opererer på en art modelniveau - at de arbejder med idealtyper i Webersk forstand, men at man er nødt til at foretage disse generaliseringer for at kunne udsige noget som helst. Spørgsmålet er blot, $\mathrm{i}$ hvilken udstrækning disse erkendelser får det nødvendige nedslag i de konkrete fremstillinger.

Denne problemstilling accentueres, når vi beskæftiger os med religioner, der ikke længere eksisterer, som fx den klassisk græske religion, eller som den førkristne nordiske religion, der er mit eget forskningsområde, og som derfor vil udgøre mit primære eksempelgrundlag for den følgende diskussion. I disse religioner har vi sjældent normative skrifter, og ofte er kilderne en mere eller mindre tilfældig sammenstilling af skrifter, der er overleveret fra forskellige perioder, samt arkæologiske artefakter. Det er ud fra disse, vi skriver en 'ægyptisk', en 'græsk' eller en 'nordisk' religionshistorie og præsenterer tro og ritualer inden for bestemte områder i bestemte perioder, således at vi giver et billede af 'religionen' i det gamle Ægypten, det klassiske Grækenland eller det førkristne Norden. I en teoretisk diskussion ville man som sagt nok være villig til at erkende 
den diversitet, der blev nævnt ovenfor; men det giver sig sjældent udslag i den fremstillingsmæssige praksis, bortset fra en vis kronologisk diversitet. Spørgsmålet er også, om, og i givet fald hvordan, man kan bruge disse betragtninger i en sådan fremstilling. Det er bl.a. dette, jeg skal komme ind på i det følgende.

Det vil altså handle om diversitet - at 'nordisk religion' ikke er en størrelse, der entydigt kan rekonstrueres ud fra kilderne. Der vil i det følgende blive diskuteret fire forskellige former for diversitet. Der kan muligvis findes flere, men disse er nok de mest problematiske. Det drejer sig om følgende:

Kronologisk diversitet

Geografisk diversitet

Social diversitet

Kognitiv diversitet

Herefter skal jeg kort komme ind på forholdet mellem rekonstruktion og virkelighed og mellem model og virkelighed, for afslutningsvis at gøre nogle overvejelser vedrørende variabler og konstanter i religion og vore muligheder for trods alt at udsige noget meningsfuldt om en størrelse som 'nordisk religion' (og alle mulige andre religioner, der ikke længere eksisterer som ideologisk eksistensgrundlag for et samfund).

\section{Kronologisk diversitet}

Religion forandrer sig over tid, og det er derfor den kronologiske diversitet, der har været mest fremtrædende i diverse fremstillinger. Det ligger i selve den historiske selvforståelse, at det er forandringer over tid, som skal kortlægges, og jeg skal derfor ikke gøre så meget ud af denne form for diversitet her. Vi kan uden videre slå fast, at uanset hvor traditionelt et samfund, vi har at gøre med, og uanset hvor stillestående, det kan forekomme, så er forandring et grundlæggende vilkår. Den kan være så ubetydelig, at man ingen mulighed har for at kortlægge den, i hvert fald ikke i nogen detaljer, hvorfor man netop også gerne deler historien ind i perioder af kortere eller længere varighed, hvor hver periode er karakteriseret ved et sæt af forandringer i forhold til den foregående. Men vi ved jo alle (eller burde i hvert fald vide det), at historisk udvikling er et kontinuum, hvor vi kan slå ned på en periode, som vi derpå betragter som en mere eller mindre statisk størrelse, velvidende at der dog konstant foregår forandringer, som vi blot først kan se manifesteret i en senere periode. Denne praksis er der ikke noget forkert i, idet det er den eneste måde, hvorpå vi kan erkende det fortidige; men det er vigtigt at være opmærksom på, at vores beskrivelse netop har status af en model, og at det altså ikke er selve virkeligheden, der beskrives. Udtrykt på en anden måde kan vi sige, at hvor virkeligheden altid er analog og uden radikale brud, men med et utal af mellemformer, så er vores måde at erkende den på digital: Hvis vi overhovedet skal kommunikere, er vi nødt til at hævde, at en farve er blå eller grøn, velvidende, at $i$ virkeligheden er der tale om et kontinuum og ikke om en forskel, der så at sige er nedlagt i naturen. Og det samme gælder religion: Den kontinuerlige forandring kan først begribes, når vi meningsfuldt, kan se, at forandringerne har gjort den foregående periode til noget andet. Så hævder vi, at vi er gået ind i en ny periode, og det giver fin mening og er som sagt en 
forudsætning for, at vi overhovedet kan begribe verden.

Periodeinddelingen er altså et udtryk for vores måde at opfatte verden på, som er uundgåelig, hvis vi vil prøve at forstå historien, og det er som sagt også indbygget i så at sige alle fremstillinger af en bestemt religion, hvorimod det ofte ligger noget tungere med erkendelsen og inddragelsen af de geografiske forskelle, som vi nu skal vende os til.

\section{Geografisk diversitet}

I det førkristne Norden forholder det sig som bekendt sådan, at hovedparten af kilderne, der siger noget om forestillingsverdenen, er forfattet på Island. ${ }^{1}$ Spørgsmålet er derfor, i hvilken udstrækning disse kilder kan tages til indtægt for forholdene i resten af Norden. Praksis har været, at fremstillinger af nordisk, eller sågar 'altgermanische', religion har benyttet disse kilder til at rekonstruere religionen i hele det nordiske eller germanske område. Det kan der være flere grunde til, hvoraf én er, at vi nu engang må benytte de kilder, vi har til rådighed. Vi kan naturligvis stille os hyperkritisk an og sige, at en kilde kun siger noget om den opfattelse, som dens forfatter havde, og at denne opfattelse ikke kan hævdes at have haft almen udbredelse. På den anden side er ingen forfatter fuldstændig isoleret fra resten af samfundet, og, hvad Norden angår, var Island heller ikke isoleret fra de skandinaviske lande. Men når det er sagt, må det også indrømmes, at der er problemer. Ét er, at det islandske samfund i mange henseender var forskelligt fra de samfundsformer, der dominerede i Norge, Sverige og Danmark i Vikingetiden. En af disse forskelle var fx, at man på Island ikke havde nogen kongemagt, hvilket givetvis har haft betydning - også for religionen. Men dette er kun én side af problemet med geografisk diversitet. Et andet er selve forestillingen om, at man havde samme religiøse opfattelse og udførte de religiøse ritualer på samme måde over hele Island eller i hele Danmark.

Hvis vi for et øjeblik forestiller os, hvordan de nordiske samfund så ud i Vikingetiden og den tidlige Middelalder, vil vi få et billede, der tager sig nogenlunde ud som følger:

Forud for migrationen til Island levede skandinaverne i de sydlige dele af Sverige og Norge samt i Danmark med samerne som naboer i nord og tyskerne i syd. Sammenlignet med andre egne af verden var afstandene ikke specielt store, selv om geografien og den relativt lave befolkningstæthed givetvis har bevirket, at man ikke besøgte nabolandsbyen hver dag. Men det var muligt at rejse over hele området, især hvis man kunne rejse med skib, og ikke kun inden for det skandinaviske område, men også længere til Kontinentaleuropa, De britiske Øer, og østpå hele vejen til Byzans og endnu længere. Befolkningen bestod mest af bønder; men mange (eller i hvert fald nogle), især mænd, drog ud om sommeren for at handle. I løbet af Vikingetiden blev det mere og mere

\footnotetext{
${ }^{1}$ At de for de flestes vedkommende er forfattet længe efter, at kristendommen var blevet indført, udgør en problemstilling, der har været et helt centralt emne for al religionshistorie vedr. den førkristne religion. Det skal imidlertid ikke beskæftige os her, hvor der først og fremmest skal fokuseres på de geografiske forhold.
} 
normalt at blive i de lande, man besøgte, vinteren over, og i Frankrig, England, Irland og Rusland bosatte man sig og blev snart påvirket af de kulturer, der hørte hjemme her. Lidt efter lidt overtog man også kristendommen. Ser vi imidlertid på dem, der blev hjemme, og det var trods alt de fleste, så må vi forestille os, at flertallet forblev hele livet i den samme landsby, sådan som vore landsbykirkegårde viser, at det også ofte var tilfældet helt op i det 19. årh. Når det var sådan, er det ikke sandsynligt, at kommunikationen med samfund, der lå blot relativt kort fra ens egen landsby, var særlig intens, i hvert fald ikke, når det gælder de lavere sociale lag (og det var igen de fleste). Vi ved med sikkerhed, at konger og medlemmer af overklassen sammen med deres følge faktisk rejste en del, og at de derfor kunne bringe kulturelle informationer fra sted til sted. Spørgsmålet er imidlertid, i hvilket omfang flertallet af befolkningen var influeret af denne kommunikation. Det mest sandsynlige er, at dette flertal forblev relativt upåvirkede, og at de fortsatte med deres skikke og med at tro, hvad de havde troet gennem århundreder, selv om både interne forskydninger og den lille påvirkning ude fra, der trods alt har fundet sted, gjorde, at hverken den religiøse praksis eller den religiøse forestillingsverden ville forblive præcis den samme. Alt i alt er det således mest sandsynligt, at den gensidige påvirkning mellem de forskellige småsamfund ikke var særlig betydelig, men at den trods alt eksisterede, og dermed indebar små forandringer over tid, som det netop blev klart i afsnittet om kronologiske forandringer.

Hvis dette billede er blot nogenlunde korrekt, må det betyde, at selv om vi evt. antager, at der en gang i en fjern fortid var tale om betydelig homogenitet (hvilket i sig selv er usikkert), så har den relative isolation betydet, at der over tid er sket en differentiering, som har indebåret, at det enkelte samfund har udviklet praksis- og forestillingsformer, som har varieret fra samfund til samfund. Omvendt har udviklingen været så langsom, at visse dybt forankrede fælles strukturer i verdensopfattelsen formentlig har fortsat med at eksistere, medens detaljerne i forskelligt omfang har varieret, både hvad angår ritualer og myter. Vi ved fra de undersøgelser, som Parry og Lord udførte i første halvdel af sidste århundrede på Balkan (og som har haft enorm betydning for både Homer-forskningen og blandt medievalister), at hver gang en episk sang blev sunget, vil den have forandret sig en lille smule, fordi enhver fortæller lægger en lille smule til og udelader andet. Hovedstrukturen kan forblive den samme, men detaljerne varierer. Når vi taler om prosafortællinger, er det sandsynligt, at denne differentieringsproces har accelereret. Man kunne argumentere for, at den kommunikation, der trods alt var tale om, også ville indebære 'lån' af en eller anden art. Hertil er at sige, at religiøse ritualer ikke udskiftes i overensstemmelse med dem fra et nabosamfund, blot fordi disse er kendt. Det gælder i nutiden og efter al sandsynlighed også i fortiden. Men samtidig er det klart, at der grundlæggende må være tale om en dobbeltbevægelse, hvor en diversitetsproces i et vist omfang modvirkes af en gensidig påvirkning.

På denne måde er der altså tale om en kombination af konstanter og variabler, præcis som vi også kender det fx i forhold til den moderne jul. Nok har de fleste et juletræ og nok synger man nogenlunde de samme sange - $\mathrm{i}$ hvert fald med nogenlunde det samme indhold, - og nok spiser man mad, der kun kan vælges inden for et ret snævert udvalg af retter (med mindre man er bevidst 'alternativ', men det var man næppe i Vikingeti- 
den). Men trods alt er der betydelige varianter, både fra familie til familie og fra egn til egn. Der er altså nogle strukturelt betingende elementer, der er fast til stede, medens andre elementer kan skiftes ud, uden at det af deltagerne opfattes som om, at det ændrer noget ved de basale ritualer og forestillinger, der forbindes med julen. Det skal her understreges, at den moderne jul altså udspiller sig i et samfund, hvor kommunikation og ikke mindst massekommunikation er det måske mest karakteristiske træk overhovedet.

Under alle omstændigheder er det tydeligt, når vi ser på nutidige samfund, at tingene ændrer sig samtidig med, at forestillinger og praksisformer fra andre kulturer bliver indarbejdet i den traditionelle kultur. Og vi kan roligt gå ud fra, at disse påvirkninger er langt stærkere i nutiden, end de var i fortiden, ganske enkelt fordi kommunikationen er så meget mere intens. Men som sagt: Påvirkning har altid eksisteret $i$ et eller andet omfang. Det indebærer, at vi, når vi arbejder med en periode som Vikingetiden, må søge at sondre i mellem, hvad der med sandsynlighed har været forskelligt fra det ene område til det andet, og hvad der kan forventes at have været relativt ens. Det skal jeg vende tilbage til nedenfor.

Der er imidlertid et andet, men dog beslægtet teoretisk spørgsmål, vi må stille i denne forbindelse, nemlig hvor vi sætter grænserne for en 'kultur'. At operere med 'Sydskandinavien' er således en mere eller mindre vilkårlig afgrænsning. Helt generelt kan man naturligvis sige, at man i en historisk undersøgelse altid af pragmatiske årsager må sætte nogle grænser: Selv om alt hænger sammen, kan man ikke beskæftige sig videnskabeligt med alt på engang. Vi må altså drage nogle grænser. Men spørgsmålet er som sagt, hvor vi sætter grænserne, og hvilken mening det har at sætte netop disse grænser. Hvad Vikingetidens Norden angår, kan man sige, at der i det mindste er nogle sproglige kriterier: På det tidspunkt, hvor Vikingetiden sætter ind, har de nordgermanske (nordiske) sprog for længst udskilt sig fra de øst- og vestgermanske. Og i virkeligheden er det sandsynligt, at netop sprogene udgør en meget præcis analogi til traditionel religion. Fx er det næppe sandsynligt, at man nord for Ejderen talte et nordgermansk sprog, medens man syd derfor talte et vestgermansk sprog. Langt mere sandsynligt er det, at der var tale om betydelige dialektforskelle over hele Skandinavien - også som vi kender det $\mathrm{i}$ dag med statsgrænser og officielle sprog osv. I Vikingetiden har overgangene mellem de forskellige områder formentlig været langt mere glidende, og vi har altså - ligesom i forhold til kronologien - vedtaget nogle kunstige skel, således at der inden for et kontinuum af varierende dialekter på et eller andet punkt er blevet så store forskelle, at vi i stedet for at tale om dialektforskelle vedtager, at nu er der tale om et nyt sprog. I forhold til religion vil et tilsvarende forhold indebære, at varianter af det 'samme' i forhold til et område bliver så store, at vi vælger at omtale det som noget 'andet' ( $\mathrm{fx}$ at nu er der ikke længere tale om germansk religion, men om keltisk). Det kan naturligvis også have noget at gøre med folkevandringer og den slags, så der reelt bliver tale om etniske forskelle; men grundlæggende vil der ofte være tale om, at vi ud fra et eller andet fiktivt centrum bevæger os længere og længere væk, så vi til sidst ikke længere kan genkende dette centrum, og så er varianterne af 'det samme' pludselig blevet til noget 'andet'.

Og selv inden for samme geografiske område er det sandsynligt, at der har hersket 
forskelle af social karakter, således at forskellige sociale klasser har haft forskellige forestillinger og udført forskellige ritualer, hvilket vi derfor kort skal se på.

\section{Social diversitet}

Vi ved, at konger og høvdinge gennemgik og udførte ritualer, der eksplicit havde at gøre med kongemagten og overtagelsen af denne. Vi ved også med stor sandsynlighed, at forskellige guder spillede en særlig rolle i forhold til bestemte sociale klasser, at Odin fx var særlig knyttet til overklassen, medens Thor i højere grad var i fokus for bønderne. Det betyder ikke, at de ikke så at sige var dele af et fælles pantheon, men blot, at den rolle, de spillede, var forskellig fra den ene sociale klasse til den anden. Det betyder heller ikke, at der ikke var berøringspunkter mellem de ritualer, der udførtes i over- og underklassen, men at de forskellige klasser havde forskellige behov og forskellige opfattelser af verden, afhængig af det punkt i det sociale hierarki, hvorfra man iagttog verden.

Dette har der været forsket særdeles meget i, og om man interesserer sig for forskellene eller for det, som er fælles, har naturligvis at gøre med den forskningsmæssige tradition, man indskriver sig i. Fx har marxistisk inspirerede forskere typisk interesseret sig for forskellene, medens mentalitetshistorikerne primært har været interesseret i de ligheder, der også eksisterede, som var fælles for alle medlemmer af et samfund, fra slaven til kongen. For begge grupper gælder det, at man ikke afviser, at der må være tale om både ligheder og forskelle, men blot at man lægger sit fokus forskellige steder.

Set i forhold til det førkristne nordiske samfund (og i øvrigt langt de fleste fortidige samfund) er man langt bedre orienteret om overklassens religion end om underklassens. Det er der naturlige forklaringer på, $i$ og med det først og fremmest var overklassen, der kunne læse og skrive, hvorfor kilderne i overvejende grad stammer fra denne. Det betyder ikke, at vi ikke ved noget om privatkult eller om bøndernes religion, men i forhold til overklassens er det meget lidt. Problemet i forskningen har imidlertid ofte været, at man, selv om disse problemer har været kendte, alligevel har brugt samtlige kilder til at belyse 'religionen', uden at være opmærksom på, at det næppe er alle informationer i kildematerialet, der belyser den 'samme' religion. Igen er det altså vigtigt at være opmærksom på, at der givetvis er træk, som faktisk har spillet en rolle i hele samfundet, men mange andre, der kun har haft betydning for bestemte grupper, eller som har været udsat for transformationer fra én klasse til en anden.

Det kan uden videre slås fast, at det er yderst kompliceret at skelne i mellem det fælles og det socialt specifikke i forhold til det nordiske, hvilket primært skyldes kildesituationen, men ikke desto mindre forekommer det afgørende, i en fremstilling af førkristen nordisk religion, at forskeren er sig disse problemer bevidst, og i det mindste forsøger at skelne mellem disse aspekter af det religiøse liv.

\section{Psykologisk og kognitiv diversitet}

Alle de foregående former for diversitet kompliceres yderligere af, at man i de fleste tilfælde har taget for givet, at man da i det mindste kunne antage, at det enkelte individ 
havde et sæt af forestillinger, der udgjorde en kohærent sammenhæng. I forhold til fx den kronologiske diversitet var der muligvis betydelige forskelle mellem den forestillingsverden, som beskrives i Tacitus' Germania, og den, der beskrives i eddaerne. Men det er jo blot forventeligt, i og med at der kan være næsten 1000 år imellem. Men selve denne opfattelse implicerer, at vi har at gøre med sammenhængende forestillingskomplekser, ikke blot geografisk og sociologisk, men også mentalt: Hvis man havde en gammel viking foran sig, ville man kunne spørge vedkommende om hans forestillingsverden, og så kunne han fortælle, hvad man virkeligt forestillede sig i Vikingetidens Norden. Med andre ord må det være kildesituationen, der gør, at vi ikke ved ordentlig besked, at vi ikke kan gøre rede for de modsætninger, der tilsyneladende er i kilderne, og som oftest tilskrives tidsmæssige forskelle på disse. For selvfølgelig har normalt begavede mennesker (hvad de fleste nordboer formentlig var) haft en logisk sammenhængende opfattelse af alle aspekter af livet.

Problemet er blot, at det er der stort set ingen moderne mennesker, der har, og der er derfor heller ingen grund til at antage, at vore forfædre havde det. Fejlantagelsen skyldes formentlig en stærk indflydelse fra teologi og filosofi, idet man inden for begge felter søger det modsigelsesfrie og det logisk sammenhængende - ganske vist ud fra visse præmisser, der filosofisk set kan diskuteres; og denne bestræbelse udvides derfor til at være noget almenmenneskeligt. Nogen er godt nok nået længere end andre, idet fx grækerne tænkte mere klart, end man gjorde i de såkaldt primitive kulturer; men grundlæggende synes der at eksistere en forestilling blandt mange forskere om, at selvmodsigelser i den enkeltes forestillingsverden udgør et problem, som den religiøse principielt vil søge at eliminere. Sådan er det bare ikke. Tilsyneladende lever de fleste mennesker udmærket, selv om deres religiøse anskuelser ind i mellem er aldeles usammenhængende. Deres guder er både i templet og i himlen, de er både antropomorfe og ikkeantropomorfe. De døde er i et paradis, men får alligevel gaver med i graven. Ritualerne indebærer, at man æder guden, men det er alligevel ikke rigtigt guden, osv. I de såkaldte højreligioner betragtes den slags som mysterier, og så er det ikke så galt, som når de primitive har lignende usammenhængende opfattelser; men hvis man er tilstrækkelig udviklet, bør tingene hænge sammen uden selvmodsigelser. Og det er da også den måde, den videnskabelige erkendelse med nødvendighed må fungere på; men religion er ikke videnskab og er måske netop karakteriseret ved denne forskel i forhold til den videnskabelige tænkning. Medens den logik, der nemlig karakteriserer den videnskabelige tænkning, er en formallogik, er den religiøse tænkning kendetegnet ved en konkret logik, som gælder inden for bestemte mentale rum, men ikke er beregnet på at være modsigelsesfri i forhold til andre mentale rum. Det indebærer, at en gud fx kan være karakteriseret på én måde i én myte, og anderledes i en anden, og undertiden vil de to karakteristikker være i direkte modstrid med hinanden. Men det betyder omvendt ikke, at alt kan siges om denne gud. Som regel er der hos forskellige gudeskikkelser tale om et semantisk centrum, som kan generere en lang række forskellige karakteristika i forskellige narrative - og for den sags skyld også rituelle - sammenhænge. Men som sagt er mange forskellige karakteristika ikke det samme som ethvert tænkeligt karakteristi- 
kum, og det er klart inden for fx den nordiske mytologi, at Odin ikke kan fremstilles som den uoplyste, der bliver narret af en jætte. Odin er klog, og en hvilken som helst myte, der inddrager Odin, må forholde sig til dette semantiske centrum: Odin er den vidende. Det kan være meget direkte tematiseret, eller det kan spille en ganske ubetydelig rolle; men han kan aldrig fremstilles som decideret dum (i så fald ville det være i en direkte polemisk sammenhæng). Der er altså grænser for, hvilke sammenhænge en gud kan indgå $i$; men inden for disse grænser er der et betydeligt rum for variationer. Modsigelser kan blandt andet opstå, ved at den enkelte figur inddrages i en bestemt rolle, som dennes semantiske felt kan udfylde, og hvor figuren udsættes for visse ting, som i andre myter ikke indgår. Fx hører vi i en beretning, at Loke får syet sine læber sammen noget som kun nævnes dette ene sted, og som aldrig ellers kommenteres. Skyldes det, at denne myte så stammer fra en anden tid eller et andet område eller en særlig social klasse? Næppe; det skyldes formodentlig ene og alene, at der i den pågældende myte er en vis logik i at lade Loke få sine læber syet sammen. Ud over denne ene myte spiller motivet ingen rolle, og derfor er der ingen grund for mytemageren til at hæfte sig nærmere ved det, uanset om man faktisk var bekendt med det eller ej. Mekanikken her er den samme, som man ser i mange tegneserier, hvor figurerne handler i overensstemmelse med deres semantiske centrum (som kan være psykologisk eller socialt bestemt); men hvad der sker i den ene episode spiller ikke rigtig nogen rolle for de øvrige. ${ }^{2}$ Den slags burde genere rationelt tænkende mennesker, som både kan konstruere broer og rumskibe, men gør det tilsyneladende ikke. Bortset fra et lille mindretal, der søger at indrette hele deres mentale verden som et sammenhængende system, er det karakteristisk, at i alle kulturer, også de moderne, lever hovedparten af befolkningen helt fint med den slags inkonsekvenser: Man er rationel i de sammenhænge, hvor det er nødvendigt; men religion er ikke en af de sammenhænge. Religion skal for at være religion være fyldt med en masse løse påstande om andre verdener med alle slags væsener, som intet fornuftigt menneske ville prøve at systematisere, men som man ikke desto mindre i bestemte situationer kan trække på, hvad enten det drejer sig om behov af intellektuel eller emotionel art, kollektive eller individuelle situationer, hvor vort normale rationelle jeg ikke slår til.

Med andre ord: Mennesket er i stand til at tænke i forskellige rum, hvorfor forskellige forestillinger ikke nødvendigvis har at gøre med forskellige kulturelle sammenhænge, der kan være historisk, geografisk eller socialt bestemt, men alene med situationsbestemte og pragmatiske måder at 'cope' med omverdenen på.

\section{Model og virkelighed}

Rekonstruktion af en fortidig virkelighed indebærer altid en form for reduktionisme: $\mathrm{Vi}$

\footnotetext{
${ }^{2}$ Af samme grund er det i øvrigt interessant, at en historie som Ringenes Herre, der ofte betragtes som meget mytisk, i virkeligheden er meget lidt mytisk. Den er simpelthen alt for sammenhængende, og figurerne handler i overensstemmelse med deres slægts historiske bestemmelse generationer tilbage. For at kunne kalde den mytisk, mangler den typisk mytiske inkonsekvenser. Det er derimod en moderne roman, som opstiller et fiktivt univers, men mytisk er den ikke, i hvert fald ikke i sin narrative form.
} 
prøver at isolere et felt, fx klædedragter, velvidende, at en total rekonstruktion af dette felt ville indebære alt mulig andet: teknologi, historie, sociale koder, økonomi osv. Uanset hvilket emne i en nærmere defineret fortid, vi kaster os over, vil vi af denne grund altid være nødt til at afgrænse det, således at det kun er visse aspekter, der kan tages i betragtning, og vi må derfor acceptere, at den beskrivelse af virkeligheden, vi når frem til, kun er partiel. Den udgør med andre ord en model af nogle bestemte aspekter af et afgrænset felt. Den dækker ikke den virkelige virkelighed.

Denne erkendelse er naturligvis ikke ny, og den er grundlæggende set yderst banal, selvom mange historikere agerer, som om den historiske virkelighed er en størrelse, der kan gives en beskrivelse af, som en art spejlbillede af den. Hvorom alt er, kan man hævde, at kvaliteten af det historiske arbejde svarer til kvaliteten af modellen. For skønt en model af virkeligheden ikke skal forveksles med virkeligheden selv, må et afgørende kriterium for at evaluere modellen være, i hvilken grad den belyser virkeligheden, sådan som denne anskues af forskere fra forskellige discipliner, både inden for natur- og for humanvidenskab. At sådanne anskuelser ændrer sig fra periode til periode, er indlysende. I det 19. årh. opfattede man som bekendt myter som udsagn om naturens gang, medens det 20. årh.s funktionalisme så myterne som udsagn om den sociale orden eller relationen mellem de sociale klasser. Kvaliteten af modellen er således afhængig af måden, hvorpå vi opfatter virkeligheden. Dette indebærer selvfølgelig, at det 'objektivistiske' synspunkt, at vi kan nærme os virkeligheden - og herunder ikke mindst de historiske virkeligheder - uden fordomme, er udelukket. Dette kunne lyde som rendyrket relativisme: Det 19. årh.'s syn på myterne var lige så godt som det 20. årh.'s, fordi det nu engang var den måde folk opfattede virkeligheden på dengang. Dette er imidlertid ikke pointen. For nok kan man sige, at 'modellerne' i det 19. årh. var gode efter den tids standard, men den var så til gengæld heller ikke så høj som i det 20. årh. Det er indlysende, når vi taler om naturvidenskaben, som alle formentlig kan blive enige om, har gjort enorme fremskridt. Den har opstillet modeller, som, selv om de stadig 'kun' er modeller, så er i stand til at beskrive virkeligheden langt bedre, end det tidligere var tilfældet. Men også kulturvidenskaben har gjort fremskridt, således at vi i dag har langt bedre redskaber til at rekonstruere virkeligheden og dermed opstille modeller, end vi tidligere havde. Der er altså ikke på nogen måde tale om en 'anything goes' teori, for noget er bedre end andet, og dermed er der også ting, man på et givet tidspunkt ikke meningsfuldt vil kunne sige om den fortidige virkelighed.

Fremskridtene i det 20. årh. inden for kulturvidenskaberne skyldes primært antropologien, som på et tidligt tidspunkt inddrog Freuds teorier om det ubevidste og Marx' teorier om de økonomiske kræfters indflydelse på vores mentalitet - teorier, som sammen med mange andre må tages i betragtning, når vi beskæftiger os med menneskers ageren, socialt såvel som religiøst. Selv om der næppe er mange, der i dag vil bruge Freud eller Marx uden seriøse reservationer, er der ingen tvivl om, at nogle af de grundlæggende mekanismer, som de hævdede, faktisk stemmer overens med virkeligheden og dermed bidrager til, at vi i dag kan skabe modeller, der har større deskriptionsværdi i forhold til de kulturelle faktorer, vi ønsker at beskrive fra forgangne tider, end det tidli- 
gere var tilfældet.

Rekonstruktion handler således om konstruktion af modeller - modeller, der må søge at være så nøjagtige som muligt og så realistiske som muligt. Spørgsmålet er så, hvilke kriterier, vi har at gå ud fra i lyset af den diversitet, der er talt om i det foregående. Eller med andre ord: Hvad er det egentlig, vi rekonstruerer, når vi beskriver fx 'nordisk religion'? Er det opfattelsen hos et bestemt individ i en bestemt situation, eller er det trods alt mere generelt end som så?

\section{Rekonstruktion af en dekonstrueret virkelighed}

Det er oplagt, at hvis alle individer tænkte forskelligt, kunne vi ikke tale om 'religion' i betydningen et bestemt world view eller et system af forestillinger, der deltes af en bestemt gruppe af mennesker. Vi kunne ikke engang tale om et bestemt individs forestillingsverden, da en sådan ville variere fra diskurs til diskurs. Så hvad er der tilbage? Skal vi helt opgive termen religion?

Jeg mener imidlertid ikke, at dette er den nødvendige konklusion. For uanset hvor varierende kildematerialet er, og uanset, hvad vi har lært om individuel religiøsitet osv., giver det trods alt mening at tale om nordisk religion, selv om den var mere differentieret, end de fleste håndbøger hævder. På trods af alle reservationer tyder alt på, at forskellene inden for det nordiske område var mindre end variationerne i mellem fx nordisk og keltisk religion eller nordisk og romersk religion, for ikke at tale om forskellene i forhold til kristendommen. Hvad er grundene til det? Hvad er det præcist, der - skønt på en vag måde - binder dette world view med alle de forventede variationer sammen, så det trods alt giver mening at tale om nordisk religion, eller endog germansk eller indoeuropæisk religion? Jeg mener, der er flere årsager til dette, men af pladshensyn skal jeg kun nævne et enkelt.

Som i mange andre humanistiske fag er den lingvistiske parallel instruktiv, som jeg allerede har været inde på - og måske ikke kun som en analogi. I det kontinuum, som sprogvariationer udgør, er det let at eftervise, at selvom der var forskelle på både germanske og nordiske dialekter, var der i hvert fald blandt overklassen (det var dem, der forfattede fx runeindskrifterne) en enshed, der var markant $i$ forhold til de omgivende sprog (samisk, keltisk, latinsk mfl.), og som bandt dem sammen til det, vi i dag kalder de germanske sprog. Selv om der har været flydende grænser mellem dialektale varianter på den ene side og disse andre sprog på den anden side, når det kommer til befolkninger, der levede i grænseregionerne, har man over store afstande, alle dialektale forskelle til trods, kunnet forstå hinanden nogenlunde problemfrit, hvorimod man ikke kunne forstå fx latin og keltisk. I et samfund, hvor der ikke eksisterede massemedier, som kunne påvirke individerne i forskellig retning, har denne sproglige homogenitet som sagt primært i de højere samfundslag udstukket nogle fælles forestillinger, eller rettere sagt nogle fælles diskursive muligheder, som har udmøntet sig i et world view, der har sat nogle grænser i forhold til andre diskursive muligheder. Det er derfor nogle overordnede strukturer, som har dannet rammerne for, hvad vi meningsfuldt kan kalde 'nordisk religion'. I den forstand adskiller den måde, man må arbejde med nordisk reli- 
gion på, sig ikke afgørende fra den måde, hvorpå Dumézil arbejdede med 'indoeuropæisk religion', hvor det jo også var detaljernes betydning for strukturen, der var på spil. Den afgrænsning i forhold til det geografiske og kulturelle rum, som der er tale om, når vi bevæger os fra det indoeuropæiske til det germanske eller nordiske, indebærer imidlertid, at også en anden type ligheder, udover de strukturelle, kan bringes i spil. Hvor det jo netop var typisk for Dumézil, at han ikke tillagde de sproglige ligheder i form af religiøse termer (fx gudenavne) nogen særlig betydning på grund af de store afstande $\mathrm{i}$ både tid og rum mellem enkeltkulturerne, forholder det sig anderledes, når vi snævrer feltet ind. Flere af gudenavnene og andre termer med tilknytning til den religiøse sfære går således igen over hele det germanske område, hvilket kraftigt antyder, at sådanne termer og navne har været pangermanske; og endnu flere kommer til, når vi begrænser os til Norden. Alene denne relative homogenitet har med stor sandsynlighed sat nogle grænser for det spektrum af semantiske muligheder, det har været muligt at knytte til sådanne termer.

Konsekvensen af dette er, at selv om de enkelte myter har varieret fra landsby til landsby og fra periode til periode, taler alt for, at de har udgjort et relativ homogent semantisk univers. For på trods af alle variationer, der kan have form af transformationer eller ligefrem inversioner, så er det kun i tekster, der er åbenlyst polemiske (som regel med udgangspunkt $i$ et kristent, apologetisk ærinde), at vi møder opfattelser af guderne, som er uden forbindelse til deres semantiske centrum. Derfor må en nordisk religionshistorie på den ene side tage hensyn til det spektrum af variationer og den diversitet, der givetvis har været tale om, men på den anden side også have taget så meget ved lære af den strukturelle myteforskning (og her kan vi uproblematisk udstrække dette til også at gælde for ritualernes vedkommende), at den kan opstille realistiske modeller. Det indebærer, at man ikke overmodigt sætter sig for at rekonstruere detaljer i narrative forløb, der af den ene eller den anden grund er ufuldstændige, med mindre der er stærke strukturelle argumenter for det, og det indebærer, at man ikke forsøger at tolke sig frem til den 'oprindelige' mening med en myte ud fra en enkelt version. En sådan 'oprindelig' mening har givetvis aldrig eksisteret, netop fordi der dengang som i dag har eksisteret et utal af variationer i opfattelsen. Det indebærer også, at man er bevidst om, at der er forskellige niveauer i religionen i forhold til konstanter og variabler. Som det er blevet klart, så er mangen en opfattelse begrænset til et enkelt individ, eller et snævert kulturelt fællesskab, medens andre har været delt af hele samfundet over store geografiske og tidsmæssige afstande. Og disse sidste har netop befundet sig på strukturniveauet. Konkret vil en religionshistorisk fremstilling derfor være henvist til på basis af så mange kildeudsagn som muligt at opstille modeller, der kan forklare og give mening til sådanne strukturelle konfigurationer. Til det formål vil man imidlertid ofte kunne bruge detaljer i fx myterne, som muligvis har haft en begrænset udbredelse, men hvis raison d'être man ikke desto mindre kan fremanalysere ved at se dem i forhold til andre myter, der opererer inden for det samme semantiske felt, men måske med nogle helt andre mytiske udsagn, som dog i modellen har en indbyrdes sammenhæng. Det er ikke alt, der vil kunne forklares på denne måde. Meget vil stå tilbage, hvor vi ganske enkelt må 
konstatere, at vi mangler informationer for at kunne sætte det ind i dets strukturelle og semantiske kontekst: Men vi vil givetvis gøre os selv og den historiske forskning i den førkristne nordiske religion en stor tjeneste ved at erkende, at på forestillingsplanet har vi at gøre med individuelle og situationsbestemte elementer, medens det er på det diskursive niveau, vi støder på de strukturer, som vi med sandsynlighed kan anse for kollektive og styrende for det world view, som berettiger, at vi kan tale om en særlig nordisk religiøs identitet.

Jens Peter Schjødt

Lektor, dr. phil.

Afdeling for Religionsvidenskab

Aarhus Universitet 